\title{
Comparative Efficacy of Local and Systemic Antibiotic Treatment in Lactating Cows with Clinical Mastitis
}

\author{
F. Sérieys, ${ }^{1}$ Y. Raguet, ${ }^{2}$ L. Goby, ${ }^{3}$ H. Schmidt, ${ }^{4}$ and G. Friton ${ }^{5}$ \\ ${ }^{1}$ Filière Blanche, 12 Quai Duguay Trouin, 35000 Rennes, France \\ ${ }^{2}$ Véto 70, 35 Grande Rue, 70160 Faverney, France \\ ${ }^{3}$ Boehringer Ingelheim, B.P. 292, 51060 Reims, France \\ ${ }^{4}$ Harlan Bioservice for Science GmbH, 29664 Walsrode, Germany \\ ${ }^{5}$ Boehringer Ingelheim Animal Health $\mathrm{GmbH}, 55216$ Ingelheim am Rhein, Germany
}

\begin{abstract}
The intramuscular administration of penethamate hydriodide over 3 consecutive days and the intramammary administration of an ampicillin/cloxacillin combination were compared in lactating cows suffering from infectious clinical mastitis in one quarter, through an open, randomized, controlled multicenter field trial. Clinical examinations were carried out on d 1 (immediately before treatment), $3,8,17$, and 22 . Milk samples were taken from affected quarters for bacteriological analysis on $\mathrm{d} 1,17$, and 22 , and from all quarters for somatic cell count (SCC) determination on d $1,8,17$, and 22 . There was no significant difference in bacteriological and clinical cure rates between the 2 treatment groups. The systemic treatment with penethamate resulted more frequently in a reduction of the milk SCC below the threshold of 250,000 cells $/ \mathrm{mL}$. This also occurred in the adjacent quarters not affected by clinical mastitis but with an SCC above 250,000 cell $/ \mathrm{mL}$ before treatment. These findings suggest that the parenteral treatment with penethamate provides collateral cure on the quarters of the cows affected by subclinical mastitis. The number of quarters per cow affected by clinical or subclinical mastitis should be considered when selecting an antibiotic treatment by the local or systemic route.
\end{abstract}

(Key words: antibiotic treatment, administration route, comparative efficacy, mastitis)

\section{INTRODUCTION}

Insufficient contact of the antibiotic with pathogenic bacteria at the site of infection is a major cause of mastitis treatment failure (Sandholm et al., 1990). The route of administration, intramammary or parenteral, of me-

Received March 19, 2004.

Accepted September 3, 2004.

Corresponding author: Laurent Goby; e-mail: gobyl@rei. boehringer-ingelheim.com. dicinal products to treat mastitis is an important issue (Ziv, 1980a). It determines the biological barriers encountered by the active compound and the routes by which it may make contact with the causal microorganism. Theoretically, the relative interest of each route depends mainly on the location of the bacteria in the udder and the physicochemical characteristics of the therapeutic molecule used. Highly lipophilic compounds able to pass through the epithelia, such as macrolides, fluoroquinolones and penethamate hydriodide, a prodrug of benzylpenicillin, are particularly suitable for the systemic treatment of bacterial infections in the udder (Ziv, 1980c).

However, the practical recommendations for the route of treatment are heterogeneous. In northern Europe, the parenteral route is widely used to treat all types of mastitis, whereas, in other countries, it depends more on how the disease is presented, e.g., the parenteral route is often reserved for the treatment of severe clinical mastitis or chronic infections caused by Staphylococcus aureus with bacteria located in the udder parenchyma.

Clinical studies comparing the efficacy of treatments given by either intramammary or parenteral routes are rare. At drying off, for example, the systemic treatment of subclinical infections with norfloxacin resulted in a higher bacteriological cure rate than that achieved by the intramammary administration of cephapirin (Soback et al., 1990). In cases of clinical mastitis during lactation caused by an experimental infection with Streptococcus uberis, no significant difference in bacteriological cure was reported between a regimen of systemic treatment with a combination of procaine penicillin and dihydrostreptomycin (3 daily injections of $5 \mathrm{~g}$ of penicillin and $6.25 \mathrm{~g}$ of dihydrostreptomycin) and an "aggressive" intramammary treatment regimen consisting of 6 administrations of a proprietary presentation containing penethamate, dihydrostreptomycin, and framycetin (Hillerton and Kliem, 2002). In a New Zealand field trial, where Strep. uberis was the predominant causative pathogen, systemic treatment with pen- 
ethamate ( $10 \mathrm{~g}$ followed $24 \mathrm{~h}$ later by $5 \mathrm{~g}$ ) resulted in an overall bacteriological cure rate of clinical mastitis of $76.4 \%$; intramammary administration of a combination of $1 \mathrm{~g}$ of procaine penicillin and $0.5 \mathrm{~g}$ of dihydrostreptomycin at 3 consecutive milkings achieved a cure rate of $84.9 \%$ (McDougall, 1998). This difference was explained by a significantly better efficacy of the intramammary treatment against the clinical infections caused by coagulase-negative staphylococci. On the other hand, the systemic treatment with penethamate allowed collateral cure of subclinical infections present in adjacent quarters.

The aim of this field study was to compare the efficacy of 2 antibiotic treatments differing in their active compounds (penethamate or an ampicillin/cloxacillin combination), and their route of administration (parenteral vs. local). Efficacy was assessed using bacteriological cure, clinical recovery, and milk SCC.

\section{MATERIALS AND METHODS}

\section{Herds and Cows}

The study was carried out in 171 farms in northeast France by 13 veterinarian investigators. Herd size varied from 19 to 148 dairy cows with herd average milk yields between 4300 and 10,600 kg/cow per year. Three hundred twelve lactating cows was recruited for the trial. They belonged to the French Holstein (76\%) and the Montbeliarde (24\%) breeds. The majority of the recruited cows were housed in loose barns (82\%), rested on straw bedding (96\%), milked twice a day (100\%), and subjected to postmilking teat disinfection (91\%). The geometric mean of milk SCC of the cows in the last month before their inclusion in the study was approximately 200,000 cells $/ \mathrm{mL}$.

\section{Selection of Animals}

To be included in the study, cows had to meet all of the following inclusion criteria: 1) clinical mastitis in only one quarter simultaneously exhibiting udder edema and macroscopically abnormal milk without or with systemic signs; 2) parity <4 lactations; 3) stage of lactation $<6 \mathrm{mo}$; 4) no concurrent disease; 5) no teat lesions; 6) no clinical mastitis or anti-infectious or antiinflammatory treatments within the last $14 \mathrm{~d}$; and 7) no previous inclusion in the study.

To control the most significant confounding parameter, the study was stratified by parity by including the same number of cows (104) in their first, second, and third lactation.

After entry into the study, cows were withdrawn if there was deviation from the planned treatment regimens or they received additional treatment during the study period due to a concurrent disease arising or due to mastitis arising in another quarter in addition to that originally affected.

\section{Treatment}

Animals meeting the inclusion criteria were randomly allocated to a treatment, using a closed envelope method.

The systemic treatment consisted of daily intramuscular injections of penethamate hydriodide (Mamyzin/ Stop M, Boehringer Ingelheim GmbH, Ingelheim, Germany) for 3 consecutive days at a dose of $15 \mathrm{mg} / \mathrm{kg}$ of BW on d 1 , followed by $7.5 \mathrm{mg} / \mathrm{kg}$ on $\mathrm{d} 2$ and $3(1 \mu \mathrm{g}$ of penethamate hydriodide provides 1 IU of penicillin $\mathrm{G}$ ). The injections were made in the neck region, alternating the side of administration on each day of treatment.

The intramammary treatment consisted of the infusion (through the teat canal of the clinically affected quarter after disinfection of the teat end) of a proprietary combination containing $200 \mathrm{mg}$ of cloxacillin and $75 \mathrm{mg}$ of ampicillin (Ampiclox, Pfizer, Paris, France) once a day for $3 \mathrm{~d}$, according to its licensed use in France.

\section{Clinical Examinations}

Cows included in the study underwent clinical examination at $d 1,3,8,17$, and 22 . The veterinarian investigator assessed general condition, rectal temperature, heart rate, udder edema, and appearance of milk; the farmer recorded decreases in feed intake and milk yield.

Rectal temperature and heart rate were measured directly, whereas other clinical parameters were scored on a numerical scale ranging from normal to slightly, moderately, or severely impaired.

\section{Milk Sampling}

Milk samples were aseptically collected (IDF, 1981) from the affected quarters on $d 1$ (immediately before treatment), 17, and 22 for bacteriological investigations. Samples were frozen at $-20^{\circ} \mathrm{C}$ within $2 \mathrm{~h}$ of collection.

Further milk samples were collected from each quarter on $\mathrm{d} 1,8,17$, and 22 into flasks containing potassium dichromate at a final concentration of approximately $0.1 \%$ for SCC determination.

\section{Laboratory Procedures}

The bacteriological investigations were carried out by the Public Veterinary Laboratory at Vesoul (France).

Bacteriological culture and identification were performed according to the National Mastitis Council stan- 
Table 1. Cases used for evaluation and bacteriological cure.

\begin{tabular}{|c|c|c|c|}
\hline \multirow[b]{2}{*}{ Bacteriological cure } & \multicolumn{2}{|c|}{ Treatments } & \multirow[b]{2}{*}{$\begin{array}{l}\text { Statistical } \\
\text { significance }^{1}\end{array}$} \\
\hline & $\begin{array}{l}\text { Systemic } \\
\text { with } \\
\text { penethamate }\end{array}$ & $\begin{array}{l}\text { Local with } \\
\text { ampicillin/ } \\
\text { cloxacillin }\end{array}$ & \\
\hline Recruited cases & 156 & 156 & \\
\hline Deviation from protocol & 3 & 4 & \\
\hline Missing results at d 22 & 1 & 0 & \\
\hline Contaminated samples & 1 & 1 & \\
\hline Absence of isolates in milk at day 1 & 29 & 29 & \\
\hline Concurrent disease & 6 & 11 & \\
\hline Cases with evaluation of bacteriological cure & 116 & 111 & \\
\hline With additional treatment in the same quarter & 22 & 21 & \\
\hline Remaining cases & 94 & 90 & \\
\hline No. of cured animals & 63 & 51 & \\
\hline Bacteriological cure rate ${ }^{2}$ & $67.0 \%$ & $56.7 \%$ & NS \\
\hline Actual bacteriological cure rate $^{3}$ & $54.3 \%$ & $45.9 \%$ & NS \\
\hline
\end{tabular}

dard (Harmon et al., 1990). A quarter milk sample was considered contaminated when 3 or more colony types of bacteria could be isolated. Identification of specific bacterial species was performed for coagulase-positive staphylococci, CNS, streptococci, enterococci, corynebacteria, arcanobacteria, other gram-positive bacteria, enterobacteriae, and other gram-negative bacilli. Different species of yeasts were not characterized.

Quarter milk SCC were determined by the fluoroopto-electronic method using a Fossomatic 360 device (Foss Electric, Hillerød, Denmark) according to the International Dairy Federation standard (1995). Measurement was usually carried out on the day of collection within $2 \mathrm{~h}$. If this was not possible, the samples were stored at $4^{\circ} \mathrm{C}$ and tested within $2 \mathrm{~d}$.

\section{Definitions of Cure}

Bacteriological cure was considered to have been achieved if the samples taken from the affected quarter on $\mathrm{d} 17$ and 22 were free of the bacterial species isolated in the pretreatment sample. All cows with a missing or contaminated sample taken on d 1,17 , or 22 , and those negative for bacterial isolation on $\mathrm{d} 1$ were excluded from the analysis.

A bacteriological cure rate was calculated excluding cows which had to be retreated for mastitis in the same quarter as originally affected or in which the therapy of mastitis had to be changed. In addition, a so-called actual bacteriological cure rate was calculated, considering those cases as treatment failure.

Clinical cure was defined as the disappearance of clinical signs of disease which were observed on $d 1$ before treatment, in other words, by the return to normal feed intake, rectal temperature $<39.0^{\circ} \mathrm{C}$, good general condition, absence of udder edema, normal milk appearance, and normal milk yield.

\section{Statistical Analysis}

The difference in bacteriological cure between treatments were analyzed using the Cochran-Mantel-Haenszel test controlling for lactation number. The percentage of animals achieving clinical cure was compared following the same procedure. The qualitative variables, feed intake, general condition, udder edema, appearance of milk, and milk yield were analyzed at each observation day after initiation of therapy using the Cochran-Mantel-Haenszel test controlling for lactation number and pretreatment value. The continuous quantitative variables, rectal temperature and heart rate, were subjected to ANOVA with lactation number as controlled factor and pretreatment value as covariate.

Differences in the evolution of SCC on $d 8,17$, and 21 after initiation of therapy were analyzed by repeated measures ANOVA with factors treatment and lactation number and with baseline values on $d$ as covariate using logarithmically transformed values on a cow basis. Comparison between treatments was performed considering the clinically affected quarter, the clinically unaffected quarters, and all quarters of each cow, successively. Those analyses were performed considering the log transformed SCC value of individual quarters.

The evolution of the SCC was analyzed considering the inflammatory status of the quarters in relation to the threshold of 250,000 cells $/ \mathrm{mL}$ (Salionemi, 1995; Dja- 
bri et al., 2002). The quarters with SCC above the threshold of 250,000 cells $/ \mathrm{mL}$ before treatment were classified according to their SCC returning or not to below this threshold on $\mathrm{d} 8,17$, and 22 following treatment. The significance of the differences between the 2 treatments was assessed using the Fisher's exact test.

The statistical analyses were carried out using SAS software, release 6.11 (SAS Institute Inc., Cary, NC).

\section{RESULTS}

\section{Exclusions}

From the 312 lactating dairy cows recruited for the study, 85 were excluded from the calculation of the bacteriological cure rate because of absence of bacterial isolates on $\mathrm{d} 1$ (58 cows), concurrent treatments during the study period ( 17 cows), deviation from the treatment protocol (7 cows), and absent or contaminated samples (3 cows). An additional 43 cows were excluded from the calculation of the bacteriological cure rate due to additional treatments in the originally affected quarter after deterioration of its clinical condition. These exclusions were correctly balanced between the 2 treatment groups (Table 1). However, they resulted in a slightly higher, though not statistically significant, proportion of third-lactation cows in the penethamate group (37 vs. $30 \%$ ), and a correspondingly lower proportion of first-lactation cows (31 vs. $38 \%$ ).

\section{Bacteriological Cure}

Systemic treatment with penethamate resulted in a bacteriological cure rate of $67 \%$; cows treated with the intramammary preparation had a cure rate of $56.7 \%$ (Table 1). The difference was not statistically significant. Bacteriological cure with additional treatment was similar in both groups with values of $54.3 \%$ in the penethamate group and $45.9 \%$ in the local treatment group.

Staphylococcus aureus, Strep. uberis, Escherichia coli, and CNS were the predominant causative pathogens (Table 2). The cure rates of infections with Staph. aureus were identical (24\%) in the 2 treatment groups. The cure rates of the infections due to Strep. uberis, CNS, and the overall gram-positive species were higher in cows treated systemically with penethamate, although differences were not statistically significant.

\section{Clinical Cure}

The proportion of cows achieving clinical cure was similar in both groups on $\mathrm{d} 3,8,17$, and 22 , with more than $80 \%$ on d 8 and about $90 \%$ on d 22 (Table 3 ).
Table 2. Bacteriological cure for individual species.

\begin{tabular}{|c|c|c|}
\hline \multirow[b]{2}{*}{ Pathogens } & \multicolumn{2}{|c|}{ Treatments } \\
\hline & $\begin{array}{l}\text { Systemic } \\
\text { with } \\
\text { penethamate }\end{array}$ & $\begin{array}{l}\text { Local } \\
\text { with } \\
\text { ampicillin// } \\
\text { cloxacillin }\end{array}$ \\
\hline \multicolumn{3}{|c|}{ Staphylococcus aureus } \\
\hline No. of animals & 17 & 25 \\
\hline No. cured (\%) & $4(24 \%)$ & $6(24 \%)$ \\
\hline \multicolumn{3}{|c|}{ Streptococcus agalactiae } \\
\hline No. of animals & 2 & 5 \\
\hline No. cured & 1 & 3 \\
\hline \multicolumn{3}{|c|}{ Streptococcus dysagalactiae } \\
\hline No. of animals & 5 & 6 \\
\hline No. cured & 4 & 5 \\
\hline \multicolumn{3}{|c|}{ Streptococcus uberis } \\
\hline No. of animals & 23 & 17 \\
\hline No. cured (\%) & $17(74 \%)$ & $12(71 \%)$ \\
\hline \multicolumn{3}{|c|}{ Coagulase-negative staphylococci } \\
\hline No. of animals & 18 & 17 \\
\hline No. cured (\%) & $11(61 \%)$ & $9(53 \%)$ \\
\hline \multicolumn{3}{|l|}{ Enterococcus spp. } \\
\hline No. of animals & 9 & 6 \\
\hline No. cured & 5 & 2 \\
\hline \multicolumn{3}{|c|}{ Enterobacteriaceae including $E$. coli } \\
\hline No. of animals & 29 & 16 \\
\hline No. cured (\%) & $18(62 \%)$ & $12(75 \%)$ \\
\hline \multicolumn{3}{|l|}{ E. coli } \\
\hline No. of animals & 25 & 12 \\
\hline No. cured (\%) & $17(68 \%)$ & $10(83 \%)$ \\
\hline \multicolumn{3}{|c|}{ Other gram-positive bacteria } \\
\hline No. of animals & 8 & 9 \\
\hline No. cured & 6 & 7 \\
\hline \multicolumn{3}{|c|}{ Other gram-negative bacteria } \\
\hline No. of animals & 2 & 4 \\
\hline No. cured & 1 & 1 \\
\hline \multicolumn{3}{|l|}{ Yeast } \\
\hline No. of animals & 2 & 2 \\
\hline No. cured & 2 & 1 \\
\hline
\end{tabular}

The appearance of milk, udder edema, general condition, feed intake, and milk yield did not differ significantly between treatment groups throughout the trial.

Mean values of rectal temperature were below $39.0^{\circ} \mathrm{C}$ in both groups over the whole trial. The mean values of heart rate remained within a physiological range,

Table 3. Clinical cure rates.

\begin{tabular}{llll}
\hline & \multicolumn{2}{c}{ Treatments } & \\
\cline { 2 - 3 } & $\begin{array}{l}\text { Systemic with } \\
\text { penethamate }\end{array}$ & $\begin{array}{l}\text { Local with } \\
\text { ampicillin/ } \\
\text { cloxacillin }\end{array}$ & $\begin{array}{l}\text { Statistical } \\
\text { significance }\end{array}$ \\
\hline Number of cows & 94 & 90 & \\
Cure rate (\%) at: & & 33 & NS \\
Day 3 & 26 & 82 & NS \\
Day 8 & 85 & 89 & NS \\
Day 17 & 90 & 92 & NS \\
Day 22 & 90 & & \\
\hline
\end{tabular}

${ }^{1}$ Two-tailed Cochran-Mantel-Haenzel test controlling for lactation number. 
Table 4. Repeated measures analyses of variance $(\mathrm{d} 8,17,22)$ on differences between treatments with lactation number as factor and baseline value (SCC on d 1) as covariate.

\begin{tabular}{|c|c|c|c|c|c|c|c|c|c|c|}
\hline \multirow[b]{2}{*}{ Day } & \multirow[b]{2}{*}{ Treatment $^{1}$} & \multicolumn{3}{|c|}{ Affected quarters } & \multicolumn{3}{|c|}{ Unaffected quarters } & \multicolumn{3}{|c|}{ All quarters } \\
\hline & & Mean $^{2}$ & $\mathrm{SEM}^{3}$ & $P$ value & Mean & SEM & $P$ value & Mean & SEM & $P$ value \\
\hline 8 & $\begin{array}{l}\text { Systemic } \\
\text { Intramammary }\end{array}$ & $\begin{array}{l}1477 \\
1731\end{array}$ & $\begin{array}{l}0.19 \\
0.19\end{array}$ & 0.56 & $\begin{array}{l}162 \\
208\end{array}$ & $\begin{array}{l}0.12 \\
0.12\end{array}$ & 0.15 & $\begin{array}{l}294 \\
354\end{array}$ & $\begin{array}{l}0.11 \\
0.11\end{array}$ & 0.25 \\
\hline 17 & $\begin{array}{l}\text { Systemic } \\
\text { Intramammary }\end{array}$ & $\begin{array}{r}621 \\
1005\end{array}$ & $\begin{array}{l}0.21 \\
0.20\end{array}$ & 0.10 & $\begin{array}{l}145 \\
167\end{array}$ & $\begin{array}{l}0.13 \\
0.13\end{array}$ & 0.47 & $\begin{array}{l}217 \\
260\end{array}$ & $\begin{array}{l}0.12 \\
0.12\end{array}$ & 0.29 \\
\hline 22 & $\begin{array}{l}\text { Systemic } \\
\text { Intramammary }\end{array}$ & $\begin{array}{l}534 \\
838\end{array}$ & $\begin{array}{l}0.22 \\
0.21\end{array}$ & 0.15 & $\begin{array}{l}135 \\
135\end{array}$ & $\begin{array}{l}0.14 \\
0.14\end{array}$ & 0.48 & $\begin{array}{l}197 \\
230\end{array}$ & $\begin{array}{l}0.13 \\
0.13\end{array}$ & 0.41 \\
\hline
\end{tabular}

${ }^{1}$ Systemic $=$ systemic treatment with penethamate; intrammammary = local treatment with ampicillin/ cloxacillin.

${ }^{2}$ Estimated least square geometric mean $(\times 1000$ cells $/ \mathrm{mL})$.

${ }^{3}$ Standard error of the mean in ln unit.

with values under 90 beats/min in both groups during the study.

\section{Somatic Cell Counts}

Clinically affected quarters. The geometric mean values of milk SCC in clinically affected quarters were initially over $4,000,000$ cells $/ \mathrm{mL}$ in both groups on $\mathrm{d} 1$ and decreased sharply in both groups after treatment. The repeated measures ANOVA on $d$ 8, 17, and 22 showed no significant difference in the evolution of SCC between the treatments (Table 4).

The percentage of quarters with SCC returning below the threshold of 250,000 cells $/ \mathrm{mL}$ was higher on $\mathrm{d} 17$ and 22 in the group treated with penethamate (Table 5 ). The difference was statistically significant on $\mathrm{d} 17(P$ $\leq 0.05)$ and approached significance on d $22(P=0.066)$.

Clinically unaffected quarters. Repeated measures ANOVA showed no significant difference between treatments with regard to evolution of SCC of the clinically unaffected quarters (Table 4). However, the proportion of clinically unaffected quarters with SCC initially above 250,000 cells $/ \mathrm{mL}$ returning below this threshold was higher in the group receiving penethamate treatment. This difference was statistically sig- nificant on d 22 (Table 5). The proportion of clinically unaffected quarters with SCC below 250,000 cells $/ \mathrm{mL}$ on $\mathrm{d} 1$ that increased above this threshold after treatment was not significantly different between treatment groups, at d 8 (19\% in both groups), d 17 (15\% in both groups), or d 22 (14 vs. $16 \%$ ).

All quarters. The geometric mean values of milk SCC of all 4 quarters did not differ significantly between the treatment groups throughout the study period (Table 4).

The proportion of quarters (clinically affected or not) with SCC returning below the threshold of 250,000 cells $/ \mathrm{mL}$ after treatment was higher in the systemic treatment group compared with the intramammary treatment group, with values of 40 vs. $28 \%$ on $d 17$ and 43 vs. $30 \%$ on d 22 , respectively (Table 5). These differences were highly significant $(P \leq 0.01)$.

\section{DISCUSSION}

The numerical difference (8\%) observed between treatments in bacterial cure rates $(10 \%$ observed in overall cure rates) was not statistically significant. This may be due to a lack of statistical power, which was

Table 5. Percentage of quarters with milk SCC initially above the threshold of $250,000 \mathrm{cells} / \mathrm{mL}(\mathrm{d} 1$ ) returning below this threshold after treatment. ${ }^{1}$

\begin{tabular}{|c|c|c|c|c|c|c|}
\hline \multirow[b]{2}{*}{ Day of observation } & \multicolumn{2}{|c|}{ Affected quarters } & \multicolumn{2}{|c|}{ Unaffected quarters } & \multicolumn{2}{|c|}{ All quarters } \\
\hline & $\begin{array}{l}\text { Systemic } \\
\mathrm{n}=79\end{array}$ & $\begin{array}{l}\text { Local }^{\mathrm{b}} \\
\mathrm{n}=90\end{array}$ & $\begin{array}{l}\text { Systemic }^{\mathrm{a}} \\
\mathrm{n}=155\end{array}$ & $\begin{array}{l}\text { Local }^{\mathrm{b}} \\
\mathrm{n}=155\end{array}$ & $\begin{array}{l}\text { Systemic }^{\mathrm{a}} \\
\mathrm{n}=234\end{array}$ & $\begin{array}{l}\text { Local }^{\mathrm{b}} \\
\mathrm{n}=245\end{array}$ \\
\hline Day 1 & 0 & 0 & 0 & 0 & 0 & 0 \\
\hline Day 8 & 13 & 15 & 39 & 31 & 30 & 25 \\
\hline Day 17 & $35^{*}$ & 17 & 43 & 34 & $40 * *$ & 28 \\
\hline Day 22 & 38 & 25 & $45^{*}$ & 34 & $43^{* *}$ & 30 \\
\hline
\end{tabular}


dramatically reduced due to the high number of cases in which no pathogen was isolated from milk samples.

In the cases where Staph. aureus was isolated, the parenteral treatment with penethamate achieved the same bacteriological cure rate as the local treatment with the ampicillin/cloxacillin combination, despite the inactivity of benzylpenicillin against the $\beta$-lactamaseproducing strains (averaging 50\% of the isolates in France; Guérin-Faublée and Brun, 1999). It should be noted that in this study, the majority of isolated Staph. aureus was sensitive to ampicillin or cloxacillin in the intramammary treatment group, whereas in the penethamate group, the in vitro sensitivity of most of the Staph. aureus was intermediate. As the cure rate was similar after both treatments, this suggests a better efficacy of the penethamate treatment against the sensitive $\beta$-lactamase-negative strains, possibly in relation with the lower MIC of benzylpenicillin compared with cloxacillin (Guérin-Faublée and Brun, 1999); it may also be due to improved diffusion of the active ingredient in the udder tissue after administration by the parenteral route (Ziv and Storper, 1985). Therefore, the penethamate treatment (which here achieved a bacteriological cure rate of $24 \%$ in Staph. aureus clinical mastitis cases) could be more specifically indicated in herds where the predominant strain is negative to the nitrocefine test or other tests indicating the secretion of $\beta$ lactamase (Jarlov and Rosdahl, 1986).

In clinical cases caused by Strep. uberis, the bacteriological cure rate achieved by both treatments was above $70 \%$. This result is consistent with previous studies that compared the respective efficacy of a systemic administration of penethamate and an intramammary penethamate/dihydrostreptomycin/framycetin preparation (Hillerton and Kliem, 2002), or to an intramammary penicillin/dihydrostreptomycin combination (McDougall, 1998).

Enterobacteria species were identified in about $25 \%$ of the cases suitable for analysis. This low proportion probably underestimates the real incidence of these species in clinical mastitis. Absence of bacterial isolation in milk when clinical signs are present is often associated with infections due to these species (Zorah et al., 1993), especially if the milk samples have been frozen (Schukken et al., 1989). The bacteriological cure rate of $62 \%$ in the group receiving the penethamate treatment may be interpreted as spontaneous cures, which are reportedly frequent in this kind of infection (Jones, 1990).

With more than $80 \%$ of cows clinically cured on the eighth day after the start of therapy, regression of the clinical signs appeared to be satisfactory and similar for both treatments.
The study showed a tendency toward more pronounced reduction in milk SCC following systemic treatment with penethamate. The difference in the proportion of quarters returning below the threshold of 250,000 cells $/ \mathrm{mL}$ after treatment reached statistical significance on $\mathrm{d} 17$ for the clinically affected quarters, on $\mathrm{d} 22$ for the clinically unaffected quarters, and on d 17 and 22 for all quarters regardless of whether they were clinically affected before treatment. Milk SCC accurately reflects the mammary health status of quarters and is a reliable indicator of udder inflammation caused by IMI (Dohoo et al., 1984; Harmon, 1994; Barkema et al., 1999). Therefore, the decreased SCC observed after parenteral administration of penethamate in the quarters not affected by clinical mastitis may indicate a beneficial collateral effect of this treatment on quarters potentially having subclinical mastitis.

Furthermore, weak base antibiotics (such as penethamate hydriodide) concentrate in the milk following systemic treatment, more so in subclinical than in clinical mastitis, because the inflammation is mild and the milk $\mathrm{pH}$ is low (Ziv, 1980b). Ziv and Storper (1985) reported a $62.7 \%$ bacteriological cure rate in subclinical infections due to penicillin-sensitive Staph. aureus after only 2 daily injections of $5 \mathrm{~g}$ of penethamate. The recommended treatment regimen of penethamate hydriodide in France (3 daily administrations of $10 \mathrm{~g}, 5 \mathrm{~g}$, and 5 $\mathrm{g})$, achieved concentrations in milk above the minimum inhibitory concentration values of most of the sensitive pathogens over the whole treatment period (Friton et al., 2003). St. Rose et al. (2003) achieved a bacteriological cure rate of $58.6 \%$ against subclinical Strep. uberis and Streptococcus dysgalactiae infections vs. $0 \%$ in an untreated control group following the same regimen.

In The Netherlands, Barkema et al. (1997) found that the cows suffering from subclinical mastitis were affected in 2 quarters on average. In the current trial, for each quarter with clinical mastitis at the start of antibiotic treatment, there was an average of 1.2 quarters suspected of being affected by subclinical mastitis on the basis of SCC above the threshold of 250,000 cells/ $\mathrm{mL}$ (Salionemi, 1995; Djabri et al., 2002).

Consequently, when choosing an antibiotic compound and its route of administration for treatment of clinical mastitis, particular attention should be paid (besides the identification of the causative pathogen and its possible localization in the udder) to the number of quarters potentially affected by subclinical mastitis. In practice, it can be carried out on the basis of milk SCC or other means to detect quarter inflammation, such as electric conductivity or California Mastitis Test. Further studies are required to assess the respective economic interest of either intramammary or systemic antibiotic treatments according to the type of infection 
and the number of quarters per cow subject to clinical or subclinical infection.

\section{CONCLUSIONS}

This study showed that parenteral administration of penethamate hydriodide in the treatment of clinical mastitis is at least as effective as the intramammary treatment with a cloxacillin/ampicillin combination in terms of clinical and bacteriological cure. It results more frequently in a reduction of milk SCC below the threshold of 250,000 cells $/ \mathrm{mL}$. The advantage of systemic treatment may be partly explained by its collateral effect on subclinical infection present in the other quarters of the cow. Hence, in addition to pharmacological issues and infection patterns, the number of quarters per cow affected by clinical or subclinical mastitis should be considered a relevant criterion for the best choice of the antibiotic compound and its route of administration.

\section{ACKNOWLEDGMENTS}

The authors thank all investigators involved in the study and M. Vanselow, who carried out the statistical analysis.

\section{REFERENCES}

Barkema, H. W., Y. H. Schukken, T. J. G. M. Lam, D. T. Galligan, M. L. Beiboer, and A. Brand. 1997. Estimation of interdependence among quarters of the bovine udder with subclinical mastitis and implications for analysis. J. Dairy Sci. 80:1592-1599.

Barkema, H. W., J. D. Van Der Ploeg, Y. H. Schukken, T. J. G. M. Lam, G. Benedictus, and A. Brand. 1999. Management style and its association with bulk milk somatic cell count and incidence rate of clinical mastitis. J. Dairy Sci. 82:1655-1663.

Djabri, B., N. Bareille, F. Beaudeau, and H. Seegers. 2002. Quarter milk somatic cell count in infected dairy cows: A meta-analysis. Vet. Res. 33:335-357.

Dohoo, I. R., A. H. Meek, and S. W. Martin. 1984. Somatic cell counts in bovine milk: Relationships to production and clinical episodes of mastitis. Can. J. Comp. Med. 48:130-135.

Friton, G., J. J. C. Van Hattum, and D. Hörstermann. 2003. Pharmacokinetics in plasma and milk of benzylpenicillin following repeated intramuscular administration of Mamyzin (penethamate hydriodide) in lactating cows. J. Vet. Pharmacol. Ther. 26(Suppl. 1):100-101.
Guérin-Faublée, V., and Y. Brun. 1999. La résistance aux antibiotiques chez les staphylocoques d'origine animale. Revue Méd. Vét. 150:299-312.

Harmon, R. J. 1994. Physiology of mastitis and factors affecting somatic cell counts. J. Dairy Sci. 77:2103-2112.

Harmon, R. J., R. J. Eberhart, D. E. Jasper, B. E. Langlois, and R. A. Wilson. 1990. Microbial procedures for the diagnosis of bovine udder infection. 3rd ed. National Mastitis Council Inc., Arlington, VA.

Hillerton, J. E., and K. E. Kliem. 2002. Effective treatments of Streptococcus uberis clinical mastitis to minimize the use of antibiotics. J. Dairy Sci. 85:1009-1014.

International Dairy Federation. 1981. Aseptic collection of milk samples. Pages 17-18 in Laboratory Method for Use in Mastitis Work. IDF Bulletin No.132. International Dairy Federation, Brussels, Belgium.

International Dairy Federation. 1995. Enumeration of milk somatic cells. Joint IDF/ISO Standard 148 A. International Dairy Federation, Brussels, Belgium.

Jarlov, J. O., and V. T. Rosdahl. 1986. Quantitative determination of beta-lactamase production by Staphylococcus aureus strains compared to qualitative tests by a microbiological clover leaf test, achromogenic cephalosporin and a iodometric test. Acta Pathol. Microbiol. Immunol. Scand. 94:415-421.

Jones, T. O. 1990. Escherichia coli mastitis in dairy cattle. A review of the literature. Vet. Bull. 60:205-230.

McDougall, S. 1998. Efficacy of two antibiotic treatments in curing clinical and subclinical mastitis in dairy cows. N.Z. Vet. J. 46:226-232.

Salionemi, H. 1995. Use of somatic cell count in udder health work. Pages 105-110 in The Bovine Udder and Mastitis. M. Sandholm, T. Honkanen-Buzalski, L. Kaartinen, and S. Pyörälä., ed. University of Helsinki, Faculty of Veterinary Medicine, Helsinki, Finland.

Sandholm, M., L. Kaartinen, and S. Pyörälä. 1990. Bovine mastitisWhy does antibiotic therapy not always work? An overview. J. Vet. Pharmacol. Ther. 13:248-260.

St. Rose, S. G., J. M. Swinkels, W. D. J. Kremer, C. L. J. J. Kruitwagen, and R. N. Zadocks. 2003. Effect of penethamate hydriodide treatment on bacteriological cure, somatic cell count and milk production of cows and quarters with chronic subclinical Streptococcus uberis or Streptococcus dysgalactiae infection. J. Dairy Res. 70:387-394.

Soback, S., G. Ziv, M. Winkler, and A. Saran. 1990. Systemic dry cow therapy: A preliminary report. J. Dairy Sci. 73:661-666.

Schukken, Y. H., F. J. Grommers, J. A. Smit, D. Vandegeer, and A. Brand. 1989. Effect of freezing on bacteriologic cultural of mastitis milk samples. J. Dairy Sci. 72:1900-1906.

Ziv, G. 1980a. Drug selection and use in mastitis: Systematic vs. local therapy. JAVMA 176:1109-1115.

Ziv, G. 1980b. Practical pharmacokinetic aspects of mastitis therapy. 1. Parenteral treatment. Vet. Med. 75:277-290.

Ziv, G. 1980c. Practical pharmacokinetic aspects of mastitis therapy. 2. Practical and therapeutic applications. Vet. Med. 75:469-474.

Ziv, G., and M. Storper. 1985. Intramuscular treatment of subclinical staphylococcal mastitis in lactating cows with penicillin G, methicillin and their esters. J. Vet. Pharmacol. Ther. 8:276-283.

Zorah, K. T., R. C. W. Daniel, and A. J. Frost. 1993. Detection of bacterial antigens in milk samples from clinical cases of bovine mastitis in which culture is negative. Vet. Rec. 132:208-210. 